\title{
A COMPARISON OF FLAGELLAR TYPING AND PHAGE TYPING AS MEANS OF SUBDIVIDING THE O GROUPS OF PSEUDOMONAS AERUGINOSA
}

\author{
T. L. PITT \\ Division of Hospital Infection, Central Public Health Laboratory, Colindale Avenue, \\ London NW9 5 HT
}

Summary. Strains of Pseudomonas aeruginosa from hospitals were typed by $\mathrm{O}$ and $\mathrm{H}$ serology and bacteriophage typing. The $\mathrm{H}$ sera were prepared against purified flagella of six type strains.

The most common $\mathrm{O}$ serogroups were $\mathrm{O6}, \mathrm{O} 11, \mathrm{O} 16$ and $\mathrm{O} 10$, and together these groups represented more than half of the total number of strains. O subgrouping proved useful for the further division of groups $\mathrm{O} 2$ and $\mathrm{O6}$.

Percentage $\mathrm{H}$ typability was high, and many $\mathrm{H}$ patterns were found. Comparison of $\mathrm{H}$ typing and phage typing as a means of making subdivisions within $O$ groups showed that, although the general discriminatory power of the two methods was similar, $\mathrm{H}$ typing performed better than phage-typing in the more common $\mathrm{O}$ serogroups.

\section{INTRODUCTION}

O-serological typing (Habs, 1957) and pyocine typing of Pseudomonas aeruginosa by "active" or "passive" methods (Gillies and Govan, 1966; Falkiner and Keane, 1977) have proved useful for the study of explosive "common-source" outbreaks and the identification of major foci of endemic infection. Although both methods are reproducible, they lack the discrimination necessary for more detailed investigations (Parker et al., 1976). By phage typing it is possible to recognise numerous patterns of lysis (Asheshov, 1974). However, the poor reproducibility of typing patterns in field isolates of the same strain make it necessary to consider as distinct only cultures showing three or more major differences in pattern (Martin, 1971). This considerably reduces the discriminatory powers of the phage-typing method.

In this laboratory we have adopted the proposal of Meitert and Meitert (1966) and used the two typing systems in hierarchical fashion: first we subdivided $P$. aeruginosa into $\mathrm{O}$ groups, and then subdivided further the strains belonging to the same $\mathrm{O}$ group by means of their phage-typing patterns, taking account only of three or more major differences in pattern. Correspondence in phage-typing pattern between strains of different $\mathrm{O}$ groups were ignored. This practice led to a marked increase in discrimination that was 
particularly noticeable in some of the more commonly occurring $\mathrm{O}$ groups (Asheshov, 1974; Parker et al., 1976). However, a wholly serological typing system seemed an attractive alternative if it divided sufficiently the more frequent $\mathrm{O}$ groups.

Many $\mathrm{H}$-serological typing schemes have been used for the subdivision of the O groups of P. aeruginosa (Gaby, 1946; Christie, 1948; Verder and Evans, 1961; Lányi, 1970), but the $\mathrm{H}$ specificity of their sera raised against unheated whole cells and tested by agglutination has been questioned (Ansorg, Schmitt and Schwerk, 1978; Pitt, 1979). In this study, H-agglutinating sera raised against purified flagella of six $\mathrm{H}$-type strains of $P$. aeruginosa were used to divide further cultures of the same $O$ group, and the results were compared with those obtained by phage typing.

\section{MATERIALS AND METHODS}

\section{Bacterial strains}

The strains of $P$. aeruginosa used had been submitted to the laboratory for routine typing from 47 hospitals during one year. Each batch of $>5$ strains received from one hospital was taken to represent an incident of infection. From these we selected a set of "independent" strains, including in it one representative of each $\mathrm{O}$ serogroup (and one untypable strain) from each incident. We also used sets of strains belonging to the same $O$ serogroup from individual incidents, and also sub-sets of these comprising strains of the same $O$ serogroup (1) from the same patient, and (2) from different patients.

Cultures were plated on King's "A" agar (King, Ward and Raney, 1954) and incubated at $37^{\circ} \mathrm{C}$ for $18 \mathrm{~h}$. In general, if a culture gave a typical colonial form and produced pyocyanin, it was accepted to be $P$. aeruginosa. Strains atypical in these respects were identified by a set of biochemical tests based on the scheme of King and Phillips (1978).

\section{Serological typing methods}

$H$ antisera. Methods for the preparation and characterisation of $\mathrm{H}$-specific antisera, and the origin of the H-type strains, were described in the preceding paper (Pitt, 1981).

$O$ antisera. The $O$-vaccine strains representing the 17 types of the proposed International Antigenic Typing Scheme (IATS) were those described by Pitt and Erdman (1978). In addition, strains O-6a, O-6c and O-6d (see Pitt, 1979) were used for the production of sera for the subdivision of group O-6. Strain O-6d had previously been designated "type 14" by Wahba (1965) but is unrelated to IATS type 14.

O-typing sera were raised in rabbits by the method of Pitt and Erdman (1978) against the strains listed above.

Absorbed sera. $\mathrm{O}$ and $\mathrm{H}$ sera were tested in doubling dilutions for agglutination in trays with suspensions of the homologous type strains and all the heterologous type strains as described by Pitt and Erdman (1978) and Pitt (1979). Cross-reacting antibody, when present, was removed by absorption as follows. Serum for type $2 a$ : serum O-2 absorbed with (abs.) strain O-16; serum for type $2 b$ : serum 0-2b abs. O-5; serum for type 5 : serum $0-5 \mathrm{~d}$ abs. O-5; serum for type $6 a$ : serum O-6a abs. O-6d; serum for type $6 c$ : serum O-6c abs. O-6a; serum for type $6 d$ : serum O-6d abs. O-6; serum for type 16: serum O-16 abs. O-5d; serum for type $\mathrm{H}-1$ : serum $\mathrm{H}-1$ abs. $\mathrm{H}-2$; serum for type $H$-2: serum $\mathrm{H}-2$ abs. $\mathrm{H}-5$; serum for type $\mathrm{H}-4$ : serum $\mathrm{H}-4$ abs. $\mathrm{H}-6$; serum for type $\mathrm{H}-5$ : serum $\mathrm{H}-5$ abs. $\mathrm{H}-2$; and serum for type $\mathrm{H}-6$ : serum $\mathrm{H}-6$ abs. $\mathrm{H}-4$.

Typing procedure. In routine typing tests, cultures were tested with a single dilution of serum two to four times lower than the highest dilution that gave strong agglutination with the homologous strain. Cultures were tested first with four pools of $O$ sera and subsequently with 
the individual sera. Pooled $\mathrm{H}$ sera were not used in routine typing. Strains that were not $\mathrm{H}$ typable on first testing were passed twice through nitrate-containing soft agar in Craigie tubes (Pitt, 1981) and plated on agar. Cultures were re-tested by slide agglutination with the H-sera diluted to approximately one-tenth of the tray-test dilutions.

Phage typing

The method of Asheshov (1974) was used.

\section{RESULTS}

\section{O-group distribution among strains}

The percentage distribution of the $\mathrm{O}$ groups and subgroups among the 823 selected "independent" strains is shown in table I. Group O6 was the most frequent and accounted for nearly one-quarter of the strains. About one-half of the strains in this group were examined with subgrouping sera, and most of these then fell into subgroup $6 \mathrm{c}, 6 \mathrm{~d}$ or $6 \mathrm{a}$, in this order of frequency. Groups $\mathrm{O} 11$ and $\mathrm{O} 16$ were the next most frequent groups, and most of the remainder were fairly equally divided among groups $\mathrm{O} 1, \mathrm{O} 2, \mathrm{O} 3, \mathrm{O} 4, \mathrm{O} 9$ and $\mathrm{O} 10$. Groups $\mathrm{O} 7, \mathrm{O} 12$, and $\mathrm{O} 13$ were rare and only one strain of $\mathrm{O} 15$ and none of

TABLE I

Percentage distribution of $O$ groups and sub-groups among 823 selected isolates of $P$. aeruginosa from hospitals

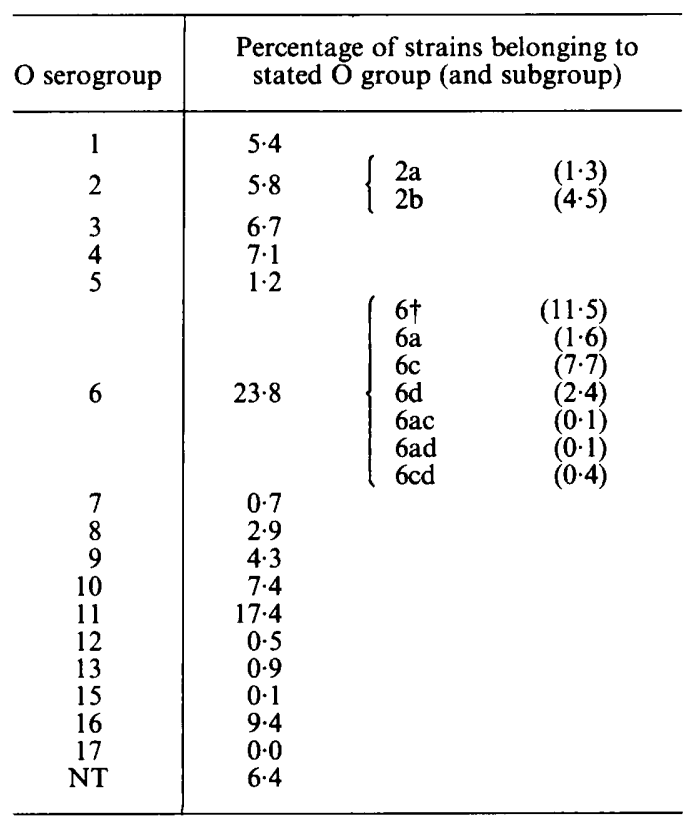

$\mathrm{NT}=$ not typable

$\dagger$ Not subgrouped. 
O17 were found. O typability was high (93\%) and among the non-typable strains only a small proportion $(<1 \%)$ were autoagglutinable or gave unstable suspensions in saline.

\section{$H$-factor distribution among $O$ groups}

Only $2.6 \%$ of the strains $(21 / 823)$ were not typable by either $\mathrm{O}$ or $\mathrm{H}$ sera and the majority of $\mathrm{H}$-untypable strains were also $\mathrm{O}$ untypable. Many $\mathrm{H}$ factors occurred in pairs and in a few cases as triplets. Table II shows the distribution of $\mathrm{H}$-typing patterns in strains of each $\mathrm{O}$ group. In all, 22 different $\mathrm{H}$-typing patterns were found; types $\mathrm{H}-3$ and $\mathrm{H}-4$ were the most common single-factor types, respectively $c .25 \%$ and $20 \%$ of the strains, and $\mathrm{H}-5$ and $\mathrm{H}-6$ were the next most common. Of the combinations of factors, types $\mathrm{H}-4,6, \mathrm{H}-2,5$, and $\mathrm{H}-3,6$ were the most frequent, but eight factor combinations were each represented by 10 or less strains.

Some correspondence between $\mathrm{H}$ factors and $\mathrm{O}$ groups was evident. $\mathrm{H}$ factors 2, 2,5 and 5 were most often associated with strains of serogroup O11; factor $\mathrm{H}-3$ with groups $\mathrm{O} 2 \mathrm{~b}, \mathrm{O} 3$ and $\mathrm{O} 4$ and in particular $\mathrm{O} 10$; factors 3 and 4 with $\mathrm{O} 16$; and factors 4 and 4,6 with members of group $\mathrm{O6}$ and its subgroups.

In total, 153 combinations of $\mathrm{O}$ and $\mathrm{H}$ types were found. Some $\mathrm{O}$ groups were satisfactorily divided by $\mathrm{H}$ typing; for example, groups $\mathrm{O} 1, \mathrm{O} 6, \mathrm{O} 9$ and O11. However, groups $\mathrm{O} 2 \mathrm{a}, \mathrm{O} 2 \mathrm{~b}, \mathrm{O} 3, \mathrm{O} 8, \mathrm{O} 10$ and $\mathrm{O} 16$ were poorly divided by $\mathrm{H}$ typing, the majority of strains in each group falling into only two or three $\mathrm{H}$ types; e.g., 72 of 77 strains of group $\mathrm{O} 16$ belonged to either H-type 3 or 4.

\section{Comparison of the $H$ serotyping and phage typing for the subdivision of strains}

The phage-typing patterns and $\mathrm{H}$ types of strains of the same $\mathrm{O}$ group from the same incident were compared to determine the number of occasions on which these methods distinguished further strains. The amount of additional subdivision of strains that was achieved in this way is shown in table III. This shows that 119 strains were defined by $\mathrm{O}$ grouping alone and this number was increased to 188 by the addition of phage typing and to $202 \mathrm{by} \mathrm{H}$ typing. That is, there were 69 and 83 occasions on which infections occurring in the same hospital at the same time due to members of the same $O$ group were distinguished respectively by their phage-typing patterns or by their flagellar antigenic structure.

It was evident that the apparently increased discrimination obtained by $\mathrm{H}$ typing was restricted to the two most common serogroups, O6 and O11. In the latter group, $\mathrm{H}$ typing distinguished 18 more strains than did phage typing. However, the phage typability of this group was considerably less than that of other groups. Table IV shows that only about one-half of O11 strains were typable by phage in comparison with a general phage-typability rate for all strains of greater than $80 \%$. Furthermore, the mean number of lytic reactions per typable O11 strain was markedly lower than the average value of 3.4 reactions per strain for all serogroups. In contrast, the value for strains of 
TABLE II

Distribution of $H$ factors among strains of $P$. aeruginosa of different $O$ serogroups

\begin{tabular}{|c|c|c|c|c|c|c|c|c|c|c|c|c|c|c|c|c|c|c|c|c|c|c|c|c|c|}
\hline \multirow{2}{*}{$\begin{array}{l}\text { O group } \\
\text { or } \\
\text { subgroup }\end{array}$} & \multirow{2}{*}{$\begin{array}{c}\text { Number } \\
\text { of } \\
\text { strains }\end{array}$} & \multicolumn{23}{|c|}{ Number (and percentage) of strains in the stated $\mathrm{O}$ group or subgroup with $\mathrm{H}$ factor or factors } & \multirow{2}{*}{$\begin{array}{c}\text { Number } \\
\text { of } \mathrm{H} \\
\text { types }\end{array}$} \\
\hline & & 1 & 1,2 & $1,2,5$ & 1.3 & 1.4 & 1,5 & 1,6 & 2 & 2,3 & 2,4 & 2,5 & $2,5,6$ & 2,6 & 3 & 3,4 & 3,6 & 4 & 4.5 & 4,6 & 5 & 5,6 & 6 & $\mathrm{NT}$ & \\
\hline 1 & 44 & 6 & $\ldots$ & $\ldots$ & 5 & 4 & 1 & 2 & 2 & $\cdots$ & $\cdots$ & $\cdots$ & $\cdots$ & & 9 & & 1 & 8 & & 1 & & 2 & 3 & $\cdots$ & 12 \\
\hline $2 \mathrm{a}$ & $\begin{array}{l}11 \\
37\end{array}$ & $\ldots$ & $\ldots$ & $\ldots$ & $\ldots$ & $\ldots$ & $\ldots$ & $\ldots$ & $\ldots$ & $\ldots$ & $\cdots$ & $\ldots$ & $\ldots$ & $\ldots$ & $\begin{array}{r}5 \\
22\end{array}$ & $\ldots$ & $\begin{array}{l}1 \\
1\end{array}$ & $\begin{array}{l}5 \\
9\end{array}$ & $\therefore$ & 3 & 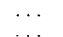 & 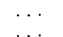 & $\mathrm{i}$ & $\dddot{i}$ & $\begin{array}{l}3 \\
5\end{array}$ \\
\hline 3 & $\begin{array}{l}31 \\
55\end{array}$ & $\cdots$ & $\cdots$ & $\ldots$ & $\cdots$ & $\ldots$ & 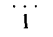 & $\dddot{i}$ & $\begin{array}{l}\cdots \\
\cdots\end{array}$ & $\ldots$ & $\ldots$ & $\ldots$ & $\ldots$ & $\ldots$ & 29 & $i$ & 9 & 6 & & & & & $\begin{array}{l}1 \\
3\end{array}$ & $\begin{array}{l}1 \\
5\end{array}$ & $\begin{array}{l}5 \\
7\end{array}$ \\
\hline 4 & 58 & $\ldots$ & $\ldots$ & $\ldots$ & $\ldots$ & 1 & $\ldots$ & $\ldots$ & $\ldots$ & $\ldots$ & $\cdots$ & $\ldots$ & $\ldots$ & $i$ & 24 & 1 & 3 & 12 & & 1 & 4 & $\ldots$ & 4 & 7 & 9 \\
\hline $\begin{array}{l}5 \\
6^{*}\end{array}$ & 10 & $\ldots$ & $\because$ & $\ldots$ & $\ldots$ & $\ldots$ & $\ldots$ & $\because$ & $\ldots$ & $\ldots$ & & $\because$ & $\ldots$ & 4 & 3 & 1 & $\ldots$ & 4 & $i$ & & & & & 1 & 5 \\
\hline $\begin{array}{l}6^{*} \\
6 a\end{array}$ & 94 & $\ldots$ & 1 & $\ldots$ & $\ldots$ & $\ldots$ & $\ldots$ & 1 & $\ldots$ & $\ldots$ & 1 & 3 & $\cdots$ & 4 & $\begin{array}{l}5 \\
4\end{array}$ & $\cdots$ & i & 29 & ${ }_{2}^{6}$ & 24 & 3 & 1 & 11 & 5 & 12 \\
\hline $\begin{array}{l}6 a \\
6 c\end{array}$ & 13 & $\cdots$ & $\ldots$ & $\ldots$ & $\ldots$ & $\ldots$ & .. & 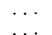 & $\cdots$ & $\ldots$ & $\ldots$ & $\dddot{3}$ & $\dddot{2}$ & $\begin{array}{l}1 \\
6\end{array}$ & $\begin{array}{l}4 \\
4\end{array}$ & $\cdots$ & 1 & $\begin{array}{l}1 \\
20\end{array}$ & $\frac{2}{3}$ & 12 & 4 & 2 & $\begin{array}{l}1 \\
4\end{array}$ & $\frac{1}{3}$ & 8 \\
\hline $\begin{array}{l}b c \\
6 d\end{array}$ & $\begin{array}{r}63 \\
20\end{array}$ & $\cdots$ & $\ldots$ & $\ldots$ & $\cdots$ & $\cdots$ & i & $\ldots$ & $i$ & $\cdots$ & $\ldots$ & i & $\ldots$ & 1 & 1 & 2 & $\ldots$ & 4 & 2 & $\begin{array}{r}12 \\
4\end{array}$ & 4 & $\frac{2}{2}$ & 4 & 3 & 10 \\
\hline $6 \mathrm{ac}$ & $\begin{array}{r}20 \\
1\end{array}$ & $\cdots$ & $\cdots$ & $\cdots$ & $\cdots$ & $\ldots$ & 3 & $\ldots$ & $\ldots$ & $\ldots$ & $\ldots$ & $\ldots$ & $\ldots$ & $\ldots$ & .. & $\ldots$ & .. & 1 & & & $\ldots$ & $\ldots$ & $\ldots$ & $\ldots$ & 11 \\
\hline 6ad & 1 & $\ldots$ & $\ldots$ & $\ldots$ & $\cdots$ & $\cdots$ & $\ldots$ & $\therefore$ & $\ldots$ & $\ldots$ & $\ldots$ & $\ldots$ & $\ldots$ & $\ldots$ & $\ldots$ & $\ldots$ & .. & & $\ldots$ & 1 & $\ldots$ & $\ldots$ & $\ldots$ & $\ldots$ & 1 \\
\hline $\begin{array}{l}6 \mathrm{~cd} \\
7\end{array}$ & 3 & $\ldots$ & $\ldots$ & $\ldots$ & $\ldots$ & $\ldots$ & $\cdots$ & $\cdot$ & $\cdots$ & $\cdots$ & $\cdots$ & $\ldots$ & $\cdots$ & $\cdots$ & $\dddot{2}$ & $\cdots$ & $\ldots$ & 2 & $\ldots$ & 1 & $\ldots$ & & $\ldots$ & $\cdots$ & 2 \\
\hline 8 & $\begin{array}{r}6 \\
24\end{array}$ & $\cdots$ & $\cdots$ & $\cdots$ & $\cdots$ & $\ldots$ & $\cdots$ & $\because$ & $\cdots$ & $\ldots$ & $\ldots$ & $\cdots$ & $\cdots$ & $i$ & 11 & $\ldots$ & 1 & & $\ldots$ & 3 & $\cdots$ & $\ldots$ & 9 & $\frac{1}{2}$ & 4 \\
\hline 9 & 36 & $i$ & $\ldots$ & $i$ & $\ldots$ & $\ldots$ & $i$ & 2 & $\ldots$ & $\ldots$ & $\ldots$ & $i$ & $\ldots$ & 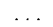 & 2 & $\ldots$ & 2 & 9 & $i$ & $\ldots$ & 7 & 2 & 4 & 3 & $\begin{array}{r}4 \\
12\end{array}$ \\
\hline & 61 & i & 1 & & 1 & & & $\ldots$ & & 1 & $\ldots$ & i & & 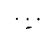 & 41 & $\ldots$ & 5 & 1 & $\ldots$ & & 2 & & 3 & 4 & 10 \\
\hline $\begin{array}{l}11 \\
12\end{array}$ & 145 & $\ldots$ & 3 & 2 & 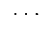 & 1 & 7 & $\ldots$ & 19 & 2 & 2 & 28 & 2 & 5 & 4 & $\cdots$ & $\cdots$ & 6 & $\cdots$ & 2 & 37 & 15 & 6 & 4 & 16 \\
\hline $\begin{array}{l}12 \\
13\end{array}$ & 4 & $\cdots$ & $i$ & $\cdots$ & 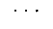 & $\cdots$ & & $\cdots$ & $\cdots$ & & $\cdots$ & $\cdots$ & $\cdots$ & $\cdots$ & 3 & $\cdots$ & i & $\cdots$ & $\cdots$ & $\cdots$ & $\cdots$ & $\cdots$ & 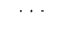 & 1 & 1 \\
\hline 15 & 1 & $\ldots$ & $\ldots$ & $\ldots$ & $\cdots$ & $\cdots$ & $\cdots$ & $\cdots$ & $\cdots$ & $\cdots$ & $\cdots$ & $\cdots$ & $\cdots$ & $\ldots$ & 1 & $\cdots$ & 1 & $\cdots$ & $\cdots$ & $\cdots$ & $\cdots$ & $\cdots$ & $\cdots$ & 3 & $\begin{array}{l}3 \\
1\end{array}$ \\
\hline 16 & 77 & $\ldots$ & $\cdots$ & $\ldots$ & $\ldots$ & $\ldots$ & $\ldots$ & $\ldots$ & $\ldots$ & $\ldots$ & $\cdots$ & $\cdots$ & $\cdots$ & $\therefore$ & 23 & 4 & 2 & 39 & 1 & 4 & $\cdots$ & .. & & 3 & 7 \\
\hline $\begin{array}{l}\text { NT } \\
\text { Any }\end{array}$ & 52 & & $\cdots$ & $\ldots$ & $\ldots$ & $\ldots$ & 1 & $\ldots$ & 3 & & & 1 & & & & 1 & 4 & & 1 & & 4 & 1 & 1 & 21 & 11 \\
\hline Any & 823 & $\begin{array}{c}8 \\
(1.0)\end{array}$ & $\begin{array}{c}6 \\
(0 \cdot 7)\end{array}$ & $\begin{array}{c}3 \\
(0 \cdot 4)\end{array}$ & $\begin{array}{c}6 \\
(0 \cdot 7)\end{array}$ & $\begin{array}{c}6 \\
(0 \cdot 7)\end{array}$ & $\begin{array}{c}12 \\
(1 \cdot 5)\end{array}$ & $\begin{array}{c}6 \\
\left(0^{\circ} \cdot 7\right)\end{array}$ & $\begin{array}{l}25 \\
(3-0)\end{array}$ & $(0 \cdot 4)$ & $\begin{array}{c}3 \\
(0 \cdot 4)\end{array}$ & $\begin{array}{c}38 \\
(4 \cdot 6)\end{array}$ & $\begin{array}{c}4 \\
(0.5)\end{array}$ & $\begin{array}{l}19 \\
(2 \cdot 3)\end{array}$ & $\begin{array}{l}201 \\
(24 \cdot 4)\end{array}$ & $\begin{array}{c}10 \\
(1 \cdot 2)\end{array}$ & $\begin{array}{c}31 \\
(3 \cdot 8)\end{array}$ & $\begin{array}{c}164 \\
(19.9)\end{array}$ & $\begin{array}{c}17 \\
(2 \cdot 1)\end{array}$ & $\begin{array}{c}58 \\
(7.0)\end{array}$ & $\begin{array}{c}61 \\
(7 \cdot 4)\end{array}$ & $\begin{array}{c}25 \\
(3 \cdot 0)\end{array}$ & $\begin{array}{c}52 \\
(6 \cdot 3)\end{array}$ & $\begin{array}{c}65 \\
(7.9)\end{array}$ & 153 \\
\hline
\end{tabular}

$\mathrm{NT}=$ untypable. 
group O6 and its subtypes was 4.3 reactions per strain. More than $90 \%$ of strains in serogroups $\mathrm{O} 1, \mathrm{O} 3$ and $\mathrm{O} 9$ were typable by phage and the highest number of lytic reactions was found in group $\mathrm{O} 3$.

It follows, therefore, that there was a greater possibility that phage typing would distinguish strains within groups with a broad range of phage

TABLE III

Comparison of the strain definition achieved by phage and $H$ typing of $P$. aeruginosa within the same O group*

\begin{tabular}{c|ccc}
\hline & \multicolumn{3}{|c}{$\begin{array}{c}\text { Number of distinct strainst defined by } \mathrm{O} \\
\text { grouping }\end{array}$} \\
\cline { 2 - 4 } Ogroup & alone & and phage typing & and $\mathrm{H}$ typing \\
\hline 1 & 4 & 8 & 8 \\
2 & 7 & 15 & 8 \\
3 & 9 & 19 & 15 \\
4 & 4 & 5 & 7 \\
6 & 40 & 66 & 72 \\
8 & 2 & 2 & 2 \\
9 & 6 & 9 & 8 \\
10 & 9 & 13 & 13 \\
11 & 28 & 38 & 56 \\
16 & 10 & 13 & 13 \\
\hline Any & 119 & 188 & 202 \\
\hline
\end{tabular}

* Including O-serological subgrouping.

† Strains submitted for typing from the same hospital on the same occasion.

TABLE IV

Percentage of strains of different $O$ groups* of $P$. aeruginos a typable by phage, and mean number of phage lytic reactions per typable strain

\begin{tabular}{|c|c|c|c|}
\hline $\mathrm{O}$ group & $\begin{array}{l}\text { Number of } \\
\text { of strains }\end{array}$ & $\begin{array}{c}\text { Percentage } \\
\text { phage } \\
\text { typable }\end{array}$ & $\begin{array}{l}\text { Mean number } \\
\text { of reactions }\end{array}$ \\
\hline $\begin{array}{l}1 \\
2 \mathrm{a} \\
2 \mathrm{~b} \\
3 \\
4 \\
5 \\
6 \\
6 \mathrm{a} \\
6 \mathrm{c} \\
6 \mathrm{~d} \\
8 \\
9 \\
10 \\
11 \\
16 \\
\mathrm{NT}\end{array}$ & $\begin{array}{r}44 \\
11 \\
37 \\
55 \\
58 \\
10 \\
94 \\
13 \\
63 \\
20 \\
24 \\
36 \\
61 \\
145 \\
77 \\
65\end{array}$ & $\begin{array}{l}95 \cdot 4 \\
72 \cdot 7 \\
89 \cdot 1 \\
92 \cdot 7 \\
79 \cdot 3 \\
70 \cdot 0 \\
92 \cdot 5 \\
84 \cdot 6 \\
88 \cdot 8 \\
95 \cdot 0 \\
87 \cdot 5 \\
91 \cdot 6 \\
70 \cdot 5 \\
54 \cdot 5 \\
84 \cdot 4 \\
49 \cdot 2\end{array}$ & $\begin{array}{l}4 \cdot 4 \\
3 \cdot 4 \\
2 \cdot 9 \\
6 \cdot 0 \\
2 \cdot 0 \\
1 \cdot 7 \\
4 \cdot 4 \\
4 \cdot 5 \\
3 \cdot 4 \\
4 \cdot 8 \\
1.7 \\
5 \cdot 7 \\
1 \cdot 7 \\
2.5 \\
3.1 \\
2.9\end{array}$ \\
\hline Any & 813 & $81 \cdot 1$ & $3 \cdot 4$ \\
\hline
\end{tabular}

* Represented by not less than 10 strains. 
TABLE V

Assessment of results of $H$ typing of sets of supposedly related isolates ${ }^{*}$ of $P$. aeruginosa

\begin{tabular}{|c|c|c|c|c|}
\hline \multirow{2}{*}{ Relationship } & \multirow{2}{*}{ H type } & \multicolumn{3}{|c|}{$\begin{array}{c}\text { Number of comparisons in } \\
\text { which the phage-typing } \\
\text { pattern was }\end{array}$} \\
\hline & & $\begin{array}{c}\text { same } \\
(0-1) \dagger\end{array}$ & $\underset{(2) \dagger}{\operatorname{similar}}$ & $\begin{array}{c}\text { different } \\
(>3) \dagger\end{array}$ \\
\hline $\begin{array}{c}\text { Same } \\
\text { patient }\end{array}$ & $\begin{array}{c}\text { Same } \\
\text { Different }\end{array}$ & $\begin{array}{r}147 \\
0\end{array}$ & $\begin{array}{r}20 \\
0\end{array}$ & $\begin{array}{r}10 \\
5\end{array}$ \\
\hline $\begin{array}{c}\text { Different } \\
\text { patient }\end{array}$ & $\begin{array}{c}\text { Same } \\
\text { Different }\end{array}$ & $\begin{array}{r}139 \\
15\end{array}$ & $\begin{array}{l}28 \\
25\end{array}$ & $\begin{array}{l}13 \\
36\end{array}$ \\
\hline
\end{tabular}

\footnotetext{
* Belonging to the same $O$ group, submitted for typing from the same hospital in the same batch of cultures, and with the stated epidemiological relationship.

$\dagger$ Number of major differences in pattern.
}

susceptibility than in those groups that contained a large number of untypable strains. Examination of the frequency of lysis of strains within serogroups by individual phages did not reveal any marked general correspondence between susceptibility to particular phages and $\mathrm{O}$ groups. However, a large proportion of strains in some groups were lysed by only three or four phages, and in group O10 in particular lysis by two phages predominated.

\section{Stability of the $H$ types of strains}

The stability of the $\mathrm{H}$-agglutination reactions of field strains was assessed by testing by slide agglutination 10 colonies each of 10 different strains which had been incubated at $37^{\circ} \mathrm{C}$ overnight. All colonies were agglutinated by sera to their respective $\mathrm{H}$ types and, of the 100 tested, three only gave weak reactions with a single additional serum.

The 100 colonies were subcultured to agar slopes, incubated at $37^{\circ} \mathrm{C}$ overnight and stored in the dark at room temperature for one month. Slide agglutination tests showed that nine colonies, derived from two strains, each exhibited single weak reactions and one colony was agglutinated by two sera.

\section{Assessment of the epidemiological value of $H$ typing}

The epidemiological value of flagellar-antigen typing was evaluated in the following way. Groups of strains from the same incident, belonging to the same $O$ group, and (1) from the same patient, or (2) from different patients were used. Comparisons were made of the H-typing and phage-typing results given by pairs of strains in each group, each strain being compared with the rest. Multiple isolates from the same patient were first used to check the reproducibility of the typing method, on the assumption that two or more strains isolated at about the same time from one patient, and belonging to the same $\mathrm{O}$ group, were very likely to be of the same strain. Table $\mathrm{V}$ shows that in 182 comparisons of such pairs of isolates, five pairs belonged to different $\mathrm{H}$ 
types; all five differed significantly in phage-typing pattern and were almost certainly distinct strains. The remaining 177 comparisons, in which both strains were of the same $\mathrm{H}$ type, included 10 pairs in which the phage-typing patterns were significantly different; these might be attributable either to "error" in the phage-typing, which is believed to occur in 3-5\% of comparisons even when the "three-major-differences" rule is applied (Martin 1971; Asheshov 1974), or to instances in which the phage-typing system was the more discriminatory. However, in all 167 comparisons in which the phage-typing results suggested that pairs belonged to the same strain, the H-typing results suggested a similar conclusion. Thus, within the limits of discrimination possibly by phage typing, no instances of "error" in $\mathrm{H}$ typing were revealed.

Isolates from different patients in the same incident were next used to compare the discriminatory power of $\mathrm{H}$ typing and phage typing on the assumption that both typing systems, as interpreted, gave totally "correct" answers. Of the 256 possible combinations (sum of all numbers), 49 indicated that pairs of strains were distinguishable by phage typing according to the "three-major-differences" rule, and 76 indicated that pairs of strains were distinguishable by $\mathrm{H}$ typing. Thirteen distinctions could be made by phage typing alone (same $\mathrm{H}$ type but with three phage differences) and 40 by $\mathrm{H}$ typing alone (different $\mathrm{H}$ type but similar phage pattern). In the comparisons of the 53 pairs of strains that showed some difference in phage-typing pattern but could not be strictly considered distinguishable, 25 were of a different $\mathrm{H}$ type.

\section{Discussion}

The distribution of $\mathrm{O}$ serogroups amongst clinical isolates of $P$. aeruginosa in Britain has changed little over the last 15 years. Wahba (1964) found that groups $\mathrm{O} 6$ and $\mathrm{O} 11$ were frequently isolated from patients and the hospital environment and these groups also predominated in the study of Asheshov (1974) and Parker et al. (1976). Groups O6 and O11 accounted for nearly 40\% of all strains in this study, but the introduction of subgrouping was successful in further dividing group O6. However, because the four most common groups $(\mathrm{O} 6, \mathrm{O} 11, \mathrm{O} 16$ and $\mathrm{O} 10)$ accounted for over one-half of the strains, $\mathrm{O}$ serogrouping alone was not sufficiently discriminatory for many types of epidemiological investigation.

On first examination, $\mathrm{H}$ typing did not appear to offer much advantage because nearly two-thirds of the strains were agglutinated by two sera. However, the percentage typability was high, and, in all, 22 different patterns of agglutination reactions were recorded with the six sera. If $\mathrm{H}$-typing patterns were used to subdivide the $\mathrm{O}$ groups, $153 \mathrm{O}-\mathrm{H}$ types could be distinguished, and discrimination was highest among the most frequent $\mathrm{O}$ groups.

Jessen (1965) reported that about $5 \%$ of strains of $P$. aeruginosa were not flagellate and by inference would not react with $\mathrm{H}$-specific sera. Because less than $8 \%$ of the strains in this study were $\mathrm{H}$ untypable, it is unlikely that much improvement in typability is to be expected from the discovery of new distinct 
$\mathrm{H}$ types. On the other hand, a search for new factors to subdivide the apparently uniform antigen $\mathrm{H}-3$ may be worth while.

The comparison of the strain definition achieved by phage typing and $\mathrm{H}$ typing showed that neither was consistently better than the other. Although $\mathrm{H}$ typing defined more strains than phage typing when all $O$ groups were included, this was not always the case when individual serogroups were considered. For instance, phage typing was more successful than $\mathrm{H}$ typing in distinguishing between strains in groups $\mathrm{O} 2$ and $\mathrm{O} 3$ and fared as well as $\mathrm{H}$ typing for strains of five other $\mathrm{O}$ groups. $\mathrm{H}$ typing was marginally superior to phage typing for the subdivision of group O6 although phage typing provided a large variety of patterns. This was not the case, however, with group O11, as nearly one-half of these strains were insensitive to phage and the number of phage reactions per typable strain was low. Although some $\mathrm{H}$ factors appeared to be associated with this group (e.g., H-2 and H-5), a large variety of patterns was observed and the results appeared to be epidemiologically valid.

Recently, Vieu and Vieu (1978) observed that the majority $(90 \%)$ of strains of group O11 hydrolysed O-nitrophenyl- $\beta$-galactopyranoside (ONPG) and this character was almost exclusive to members of this serogroup. We have confirmed their findings with a limited number of routine strains (unpublished), although some strains $(12 \%)$ of other serogroups (e.g., $\mathrm{O} 2$ and $\mathrm{O} 10$ ) were, albeit weakly, also ONPG positive. Consideration of the phage insensitivity and H-group association of group Oll, in addition to this biochemical anomaly, suggests that some strains of this group may represent a distinct biotype of $P$. aeruginosa.

Serological schemes, if sufficiently discriminatory, are usually preferred to phage-typing or other "sensitivity" methods of typing because they generally show less inherent variability. To do phage typing, one must propagate and maintain a set of typing phages, though the $P$. aeruginosa typing phages are not difficult to propagate to high titres, and once produced are stable. The method of typing is simple and large batches of cultures can be conveniently typed with the aid of a mechanical device to deliver a standard volume of phage.

The method of $\mathrm{H}$ typing is also technically simple, but the procedures for the preparation of the typing reagents (Pitt, 1981) are somewhat specialised. Despite the benefits of improved discrimination and reproducibility provided by $\mathrm{H}$ typing, it may be prudent to reserve phage typing as a secondary procedure if further discrimination between strains than that provided by $\mathrm{O}-\mathrm{H}$ serology is required.

\section{REFERENCES}

ANSORG, R., SCHMitT, W. AND SCHWERK, V. 1978. Antikörperbildung gegen somatische und flagelläre antigene von Pseudomonas aeruginosa. Med. Microbiol. Immunol., 165, 181.

Asheshov, E. H. 1974. An assessment of the methods used for typing strains of Pseudomonas aeruginosa. In Proceedings of Sixth National Congress of Bacteriology, edited by A. Arseni, Leontiadi Medical Editions, Athens, p. 9.

Christie, R. 1948. Observations on the biochemical and serological characteristics of Pseudomonas pyocyanea. Aust. J. exp. Biol. med. Sci., 26, 425. 
FALKINER, F. R. AND KEANE, C. T. 1977. Epidemiological information from active and passive pyocine typing of Pseudomonas aeruginosa. J. med. Microbiol., 10, 447.

GABY, W. L. 1946. A study of the dissociative behaviour of Pseudomonas aeruginosa. J. Bact., $51,217$.

Gillies, R. R. AND Govan J. R. W. 1966. Typing of Pseudomonas pyocyanea by pyocine production. J. Path. Bact., 91, 339.

HabS, I. 1957. Untersuchungen über die O-antigene von Pseudomonas aeruginosa. Z. Hyg. InfektKr., 144, 28.

JESSEN, O. 1965. Pseudomonas aeruginosa and other green fluorescent pseudomonads, Munksgaard, Copenhagen.

KING, A. AND PHILliPS, I. 1978. The identification of pseudomonads and related bacteria in a clinical laboratory. J. med. Microbiol., 11, 165.

KING, E. O., WARD, M. K. AND RANEY, D. E. 1954. Two simple media for the demonstration of pyocyanin and fluorescein. J. Lab. clin. Med., 44, 301.

LÁNYI, B. 1970. Serological properties of Pseudomonas aeruginosa. II. Type-specific thermolabile (flagellar) antigens. Acta microbiol. hung., 17, 35.

Martin, D. R. 1971. Variation in Pseudomonas aeruginosa. Ph.D Thesis, University of London.

MEITERT, T. AND MeITERT, E. 1966. Utilisation combinée du sérotypage et de la lysotypie des souches de Pseudomonas aeruginosa en vue d'approfondir les investigations épidémiologiques. Archs. roum. Path. exp. Microbiol., 25, 427.

Parker, M. T., Pitt, T. L., Asheshov, E. H. and Martin, D. R. 1976. The selection of typing methods for Pseudomonas aeruginosa. In Proceedings of the VI international colloquium on phage typing and other laboratory methods for epidemiological surveillance, Wernigerode, GDR, 1975, vol. 2, p. 469.

PITt, T. L. 1979. A study of the heat-labile antigens of Pseudomonas aeruginosa. Ph.D Thesis, Council for National Academic Awards, London.

PITT, T. L. 1981. Preparation of agglutinating antisera specific for the flagellar antigens of Pseudomonas aeruginosa. J. med. Microbiol., 14, 251.

PItT, T. L. AND ERdman, Y. J. 1978. The specificity of agglutination reactions of Pseudomonas aeruginosa with $\mathrm{O}$ antisera. J. med. Microbiol., 11, 15.

VERDER, E. AND EVANS, J. 1961. A proposed antigenic schema for the identification of strains of Pseudomonas aeruginosa. J. infect. Dis., 109, 183.

Vieu, J. F. ANd VIeU, M. 1978. Le test à l'O.N.P.G. et l'épidémiologie de Pseudomonas aeruginosa. Med. Mal. infect., 8, 231.

WahBa, A. H. 1964. Epidemiology of hospital infection with Pseudomonas pyocyanea. Ph.D Thesis, University of London.

WaHBA, A. H. 1965. Pyocine typing of Pseudomonas pyocyanea and its relation to serological typing. Zentbl. Bakt. ParasitKde, I. Abt. Orig., 196, 389. 